\title{
Villages in the City: The Gramastha Mandals of Mumbai
}

Jonathan Galton

\section{(2) OpenEdition}

\section{Journals}

Electronic version

URL: http://journals.openedition.org/samaj/5414

DOI: $10.4000 /$ samaj. 5414

ISSN: 1960-6060

Publisher

Association pour la recherche sur l'Asie du Sud (ARAS)

Electronic reference

Jonathan Galton, «Villages in the City: The Gramastha Mandals of Mumbai », South Asia

Multidisciplinary Academic Journal [Online], 21 | 2019, Online since 31 July 2019, connection on 17

September 2019. URL : http://journals.openedition.org/samaj/5414; DOI : 10.4000/samaj.5414

This text was automatically generated on 17 September 2019.

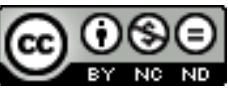

This work is licensed under a Creative Commons Attribution-NonCommercial-NoDerivatives 4.0

International License. 


\title{
Villages in the City: The Gramastha Mandals of Mumbai
}

\author{
Jonathan Galton
}

\section{Tukaram's Room}

1 Several months into my fieldwork I met Tukaram. ${ }^{1}$ He was part of a small group of young men standing outside a barber shop I had just patronized, and as so often happened they asked who I was, where I was from and what I was doing. I explained that I had come to their central Mumbai neighborhood, known as the Delisle Road BDD Chawls, to conduct a year of research ${ }^{2}$ and intimated as well as I could, in a mix of Hindi and Marathi, that I was an anthropologist interested in questions of belonging and difference.

2 I learnt that they were cousins, living together in a single room that their grandfather and friends from the same village, called Katkarwadi, had bought some decades ago. Their grandfather and later their fathers had come to Mumbai ${ }^{3}$ for work and lived in the same room, as had numerous other men from the village. Since then they had retired and were now living back in Katkarwadi, a few hundred miles southeast of Mumbai in Kolhapur District. Meanwhile, a third generation from Katkarwadi, including Tukaram and his cousins, was now living and working in the city. Some of the older cousins had been there for a decade or more already, while 22-year-old Tukaram had arrived two years previously. After this encounter we began to meet regularly, and soon enough they invited me into their room.

Chawls are a form of tenement-like building typically associated with cramped living quarters-often no more than a single small room-shared toilets and tight-knit communities. At 180 square feet, Tukaram's room is tiny and it is also dark for much of the day. In the afternoon, several young men will probably be stretched out on their bed sheets, sleeping or watching films on their phones. The light pink plaster walls on either side of them are largely obscured by vests, shirts and trousers hanging from a row of hooks. At the far end is a slightly raised area, the walls lined with off-white tiles, containing a large blue plastic water drum. This is called the mori and the room residents 
use it for washing-clothes and dishes, as well as bodies. There is no internal toilet, so the residents use common toilets located at the end of the corridor.

All round the room are signs of multiple occupancy: a shoe rack crammed with a variety of footwear; a wooden ledge piled up with trunks and suitcases; numerous stainless-steel tiffin boxes next to a spaghetti of phone chargers on a shelf above rolls of bedding. In one corner there is small wooden shrine with images of Hindu deities and in front of the balustrade is a framed picture of the Maharashtrian saint Sai Baba of Shirdi. On the door is a faded sign in Devanagari lettering that reads "Katkarwadi Gramastha Mandal".

5 A gramastha mandal is a villagers' association, and Katkarwadi Gramastha Mandal specifically exists for the benefit of Tukaram's village. There are over forty such gramastha mandals in the BDD Chawls, all operating under a similar model whereby a village committee buys one or more rooms to rent out to migrants from their village. The rental rate is usually low, between Rs 100 and Rs 500 (approximately GBP 1-5.50) per person per month. Some, like Gaowadi Gramastha Mandal (linked to Gaowadi village, near Katkarwadi), own a single room. Others own multiple rooms-five in the case of Katkarwadi Gramastha Mandal.

6 The number of occupants is typically between 10 and 20, with a median age of around 25, although in many rooms there are at least a couple of much older residents. The vast majority of the gramastha mandals I encountered in the BDD Chawls are associated with villages in Kolhapur District, in the western part of Maharashtra State. Members hence speak Marathi as their mother tongue and in most cases are Hindu. Many specifically identify as Maratha, a cluster of forward castes ${ }^{4}$ that has traditionally dominated the agricultural economy of the region surrounding Mumbai. There are smaller numbers of Buddhists who are members of the Mahar caste, a Dalit (formerly "untouchable") community that largely converted to Buddhism across Maharashtra in 1956, following the example of Mahar-born social reformer Dr. Babasaheb Ambedkar, in an attempt to escape the Hindu caste system. The one absolute constant across all gramastha mandal rooms is gender: they are exclusively for men.

7 The gramastha mandal system is by no means unique to the BDD Chawls, and can be found across Mumbai as attested by Neera Adarkar's description of "rooms taken on rent by the Gaonkari ${ }^{5}$ Mandals or village committees and converted into dormitories for the single migrants from that village at affordable rents" (2011:19). Similar brief references can be found in other Mumbai studies (e.g. Adarkar and Menon 2004; Finkelstein 2011; Prakash 2011; Valunjkar 1966), alongside more general accounts of migrant cohabitation (e.g. Chandavarkar 1994:182-88; Gore 1972), but on the whole, given its apparent ubiquity in Mumbai, this system has received surprisingly little academic attention. An exception is Hemalata Dandekar's (1986) ethnography of migration from Sugao village in western Maharashtra, which includes an account of Sugao migrants' lives together in a single room in Mumbai. Since Dandekar completed her research in the early 1980s, however, it remains a useful but somewhat outdated resource.

In this paper, therefore, I examine this little-studied manifestation of urban migration through three inter-related lenses. I consider how gramastha mandals have changed since Dandekar's study, particularly following the closure of Mumbai's cotton mills, which for many years represented their economic mainstay. I ask how living in a gramastha mandal room impacts migrants' relationships with their urban surroundings and also their villages and, significantly, how this arrangement perpetuates (in Mumbai) societal divisions that have arisen in the villages. I address these questions together in the 
following sections that examine the contexts of gramastha mandal living arrangements, working patterns and recreational or voluntary activities. I draw on my research into of eighteen gramastha mandals, which I undertook through a combination of participant observation and recorded interviews predominantly conducted in Hindi, with some use of Marathi and English. While in some gramastha mandals I had multiple acquaintances and became a regular visitor, in a few cases I met only one member on a handful of occasions.

It should be noted that while reference is paid to the families resident in the BDD Chawls and also to those former gramastha mandal members who have either retired to the village or moved elsewhere with their own families, this paper primarily considers the experiences and perspectives of young, male migrants. The conclusions I draw are therefore specifically applicable to this particular category of migrant, meaning that caution should be taken before attempting to extrapolate them to support any wider claims about migration or about Mumbai life as a whole.

\section{Circular Migration and the BDD Chawls}

10 The BDD Chawls were constructed on four sites in the 1920s by the Bombay Development Directorate (BDD) in response to a housing crisis with roots in a late nineteenth century influx of migrant labor (Caru 2011:26). Much of this migration was connected to the cotton mills that dominated Mumbai's industrial economy until the decline that followed a year-long strike in 1982-83. Although the site in Worli is the largest of the four BDD Chawls sites by some margin, my research was solely undertaken at the site on Delisle Road (officially renamed N. M. Joshi Marg) where 32 buildings are clustered around a grid of streets. Each building comprises four stories, in which ten single-room tenements are lined up either side of a wide central corridor.

11 While many gramastha mandals own rooms in the BDD Chawls, the majority of the rooms are actually owned and occupied by families. As with gramastha mandal migrants, the biggest contingent among these families belongs to the Maratha community, while Marathi-speaking Dalit Buddhists and Dalit Hindus form significant minorities. Within these communities, many families trace their roots to Kolhapur District-indeed the surrounding Delisle Road area is known as a "mini-Kolhapur"-but a substantial number hail ancestrally from the Konkan coastal districts. Alongside these Maharashtrian families and gramastha mandals live a few families belonging to non-Maharashtrian communities, including Gujarati Hindus, Goan Catholics and North Indian Muslims.

12 Despite the preponderance of families in the BDD Chawls today, anecdotal evidence from older residents suggests that in previous decades, gramastha mandals and other forms of bachelor-migrant housing would have been the most common living arrangement. ${ }^{6}$ Several of the older family men I came to know in the BDD Chawls had themselves come to Mumbai as gramastha mandal migrants, but were now living with their children in the same or a nearby building to the one they had initially occupied. As Prasad Shetty (2011) describes in a fictionalized context, chawls that were "[o]nce primarily male labourdormitories ... began changing into housing colonies for [the migrants'] families. The tenement occupancy changed from a set of friends to an extended family" (p. 61).

13 For much of the twentieth century, only a minority of gramastha mandal migrants would have stayed on in the city and bought their own property. In a study of migration to Mumbai, M.S. Gore (1972) found that over half the Maharashtrian migrants he 
interviewed planned on retiring to their villages, with only a very small proportion opting to stay in the city (p. 146). Dandekar (1986), likewise, found in the early 1980s that "most migrants cannot save enough to buy an apartment" and hence retire to Sugao, their natal village (p. 244). Out of the six cousins, including Tukaram's father, who came to Mumbai from Katkarwadi in a similar period to that of Dandekar's study, two bought houses in Mumbai, while the rest returned to the village.

This form of life-cycle oscillation is referred to as circular migration, which Deshingkar and Farrington (2009) define as "a temporary move from, followed by a return to, the normal place of residence, for purposes of employment" (p. 1). Doug Saunders argues in Arrival City (2011) that this is actually the most common form of migration, and that the "world's population shifts cityward in a back-and-forth oscillation of single individuals and clusters of villagers" (p. 38), while De Haan (1997) suggests that circular migration predates industrialization.

15 Circular migration simultaneously plays out on a short-term seasonal scale, and a regular flow of bodies, money and material between city and village is a noticeable element of gramastha mandal life. Almost always, in fact, one or more room members would be temporarily back in the village, perhaps attending a family wedding or a religious festival, or sometimes engaged in informal labor such as helping out in the family's fields. Even when in Mumbai, the village seemed to be a preoccupation for many of my interlocutors, who extolled the calm pace of life, the cool climate and the superior quality of the food and entertainment on offer in their villages. They convinced me, as Dandekar (1986) had been convinced by her Sugao interviewees decades earlier, that the "village offer[ed] a healthier environment, better food, and a more congenial social life" (p. 226). In contrast, few had a good word to say about Mumbai. An appetite for shopping malls and consumer goods notwithstanding, Tukaram referred to Mumbai in distinctly unenthusiastic terms-crowded, dirty and difficult to travel across, sentiments I heard echoed by numerous other gramastha mandal migrants.

Gidwani and Sivaramakrishnan (2003) have framed the ability of migrants to "straddle, with great facility ... two different cultural words," as "rural cosmopolitanism" (p. 341). On the other hand, where my interlocutors are concerned, living with fellow villagers in the broader surroundings of a "mini-Kolhapur" and mostly socializing as a unit, a gramastha mandal migrant can actually spend a large part of his Mumbai life in a partial simulacrum of the village itself. When I asked Ananda, from Dorli village, about his experiences in the BDD Chawls, he told me:

The village-like atmosphere is great... In the room, in the whole area, it doesn't seem like you've gone outside [the village] ... I mean you find people from nearby villages everywhere you go round here ${ }^{7}$

In her ethnography of Sugao, Dandekar (1986) describes the way Mumbai migrants remain "psychologically and socially very much a part of village society" which exerts a "tenacious hold" over them (p. 255). Likewise, in a study of migration to Mumbai from Maharashtra and Uttar Pradesh, Gore (1972) suggests "the continued presence of kin and village friends in the city" allows these migrants to "continue to function with [their] rural frame of reference even in the metropolitan community" (p. 46-47). 


\section{Reproducing Village Divisions in the Chawls}

17 How else are these rural frames of reference expressed in Mumbai through the gramastha mandal system? Adarkar (2003) argues that "[u]rbanisation generally loosens barriers," but notes that in the specific case of the BDD Chawls, "the identities of caste and religion often got solidified" and that some chawls "were exclusively inhabited by Muslims... others by dalits and/or caste Hindus." (p. 4,529). This pattern continues today: only one building has a sizeable Muslim population, while another is known as the "Catholic chawl," as evidenced by the Father Christmas murals at the entrance. Thirteen buildings have a significant Dalit population and certain others are almost exclusively occupied by Maratha families. Even these buildings can be approximately divided between those with a majority from Kolhapur District and those with a majority from the Konkan. Although it is beyond the scope of this study to fully trace the historical origins of these divisions, which are in any case hardly unusual in Mumbai, I contend here that the demographic structure of the gramastha mandals themselves provides indirect evidence of a mechanism by which village spatial divisions are reproduced in the urban built environment.

The relatively few existing academic references to gramastha mandals are typically either silent on the issue of caste, or explicitly emphasize the "esprit de corps, even among those from different castes" (Dandekar 1986:255) found in the city, in contrast to the village. As one the interviewees in Adarkar and Menon's oral history of the Mumbai cotton mills explains:

Only people from our village are allowed to stay in those galas [bachelor rooms].

There are people from all castes. (Maruti Gyandeo Satkar in Adarkar and Menon 2004:100)

Meanwhile, in a study of migration from an Uttar Pradesh village, Rowe (1973) argues that for migrants in Mumbai the "ideal of all men of a village being gaon bhai, or village brothers, has greater meaning" and "relationships among men of different castes but of the same village may be much warmer and closer [in Mumbai] than in the village" (p. 229).

Likewise, although the majority of the gramastha mandal residents I met belonged to the Maratha community, many initially informed me that their rooms were open to any (male) residents of their village, rather than being restricted to a specific caste or religion. Sameer from Gaowadi Gramastha Mandal, for example, told me on two separate occasions that any resident of Gaowadi would be welcome to live in his room. Alongside the Marathas there are other Hindu communities as well as Muslims, Christians and Buddhists in Gaowadi, any of whom would be allowed to join the gramastha mandal.

Some weeks later, however, at the birthday celebration of one of Sameer's roommates, cracks emerged in this picture of village-wide inclusivity. After being repeatedly told, unprompted, that "ham log sab Maratha hain" (we are all Marathas), I could not resist asking the men if Dalit Buddhists would be allowed live in their room. "Nahin!" (No) came the vehement response, Sameer punching the air in mock aggression. As the ensuing discussion quietened down, one of the roommates told me that, actually, "ve log a sakte hain, lekin ve nahin ate hain" (those people can come, but they don't come). Others halfagreed, suggesting that Dalits could stay for a couple of days, but could not become permanent room members. 

was unusually visceral in tone, but hardly unique in sentiment. As far as I was able to ascertain, 11 out of the 18 gramastha mandals that I had contact with restricted eligibility to Hindus, and in some cases specifically to Marathas. Meanwhile, there were two gramastha mandals whose rooms were solely occupied by Dalit Buddhists. One of these was an association composed of four villages, including one called Amrutwadi, while the other was linked to Borgaon village. Both Amrutwadi and Borgaon also have Hindu-only gramastha mandals in the BDD Chawls. only open to the descendants of the original residents, all of whom had been Marathas. My Katkarwadi interlocutors, on the other hand, told me that the Hindu-only demographic of their rooms was purely a reflection of the Hindu-only village population. Where other gramastha mandals were concerned, reasons for restricting entry to Hindus were more opaque. Some residents simply shrugged and said "niyam hai" (it's the rule). Ananda, from one of the two Buddhist-only gramastha mandals, told me that he was unsure of the rules and regulations, but regarding the Hindus in his village:

Their way of thinking is different from ours, so ... it would be inconvenient for them to live here. ${ }^{8}$

The clearest explanation came during an interview with Abhinav, a resident of (Hinduonly) Jambhe Gramastha Mandal, when I pressed him on the issue of caste restrictions. He told me that although Christians and Muslims from Jambhe can apply to live in the room, this has never happened in practice, and in general preference is given to Hindus due to their majority in the village. For Dalit Buddhists, however, residence is prohibited due to the circumstances under which the gramastha mandal rooms had initially been purchased:

Everyone was supposed to do [a] fund which, you know, will be a helping hand to us to buy a room ... but [the Dalit Buddhists] they strictly refused .... At that time they said "no we are not interested in this concept, and we will not give you anything, and we will not come with you in future as well" ... [So] the restrictions are being made, and due to that they are not allowed .... It has been strictly decided. ${ }^{9}$

While this appears to be a highly village-specific history, an almost identical story of Dalit Buddhists not contributing to the founding fund and being permanently excluded thereafter was described to me by residents of Kingaon Gramastha Mandal.

In all likelihood, these neatly rendered narratives of cause and effect mask deep historic divisions that led to the Buddhists' refusal to support the gramastha mandal. Villages across India have traditionally been divided along caste and religious lines, a separation that is both territorial and psychological, as vividly described by Kancha Ilaiah (1996) with reference to his natal Telangana village (p.1-19). Maharashtrian villages are no exception: Anupama Rao (2009) explains that the "residential area for Dalits, called the Maharwada or Baudhwada, is usually located at the southern end of the village, and is almost always outside the village boundary" (p. 230). ${ }^{10}$

One Kingaonkar told me quite bluntly that Dalit Buddhists and Hindus live in different parts of the village, and that he knew nothing about the lives of Kingaon's Buddhist migrants in Mumbai. "They cannot come to our room. They cannot come into our area [in Kingaon]. I can talk to them but I don't make friends with them. I don't like..." Members of Borgaon Gramastha Mandal were equally blunt, informing me that no Buddhists lived in their room "because of casteism," adding that "Gaon mein aisa rehte" (it's like that in the village).

South Asia Multidisciplinary Academic Journal, 21 | 2019 

living, The Triumph of the City, Edward Glaeser (2011) foregrounds the possibilities cities offer for people to "connect with a broader range of friends whose interests are well matched with their own" (p. 128). Mumbai, in particular, has been celebrated as a place of "intensity, heterogeneity and ... radical mixing" (Hansen and Verkaaik 2009:10), with "a relatively high degree of ethnically mixed neighbourhoods," at least prior to the communal riots of 1992-93 (Hansen 2001:160). We might therefore expect to encounter "friendships and alliances" in Mumbai "that could never flower in the jealous village." (Dandekar 1986:254).

Indeed, as already indicated in a gramastha mandal context, there is a tendency among some commentators to romanticize the historical unity of the city's migrant workers and their ability to pull together across community lines. Sadhav Jagre, for example, a retired foreman interviewed by Adarkar and Menon, recollects his concern over proposals in the 1950s to make Mumbai a centrally-administered Union Territory: "It would not remain a working-class Bombay .... [which] was more important to us than Marathi and nonMarathi" (Adarkar and Menon 2004:232).

Nevertheless, Valunjkar's (1966) observation that "the majority of Mahar migrants" from the Maharashtrian village he studied in the 1950s "were staying in the same chawl in Bombay" (p.72) indicates a long history of caste- or kin-based migration patterns. Moreover, Pendse, Adarkar and Finkelstein (2011) highlight the role of chawl living in allowing specific sub-regional identities to flourish in Mumbai, suggesting that both "the initial single migrant and later the families imported the village or subdivision (tahsil/ taluka) specificities to their neighbourhood" and that this level of specificity "would not have been possible without the concentration brought about by the chawl" (p. 3). This "concentration" is not necessarily incompatible with a general loosening of social barriers. In fact, the authors argue, chawls "brought about an amalgamation between different castes-often through romances and marriages" (Pendse, Adarkar and Finkelstein 2011:3). However, this social mixing had its limits, and Dalits were often "assiduously excluded from the buildings" in defiance of government regulations ( Pendse, Adarkar and Finkelstein 2011:3).

Drawing together the arguments of this and the preceding section, I suggest that gramastha mandals were a numerically dominant force in the BDD Chawls in their early decades and from the outset were divided on caste and community lines that reflected the social divisions in the villages that established them. As single male migrants brought their families to live with them, often settling down in the same buildings they had previously occupied as gramastha mandal residents, these divisions became further entrenched in a mutually reinforcing system where new arrivals-whether families or new gramastha mandals-tended to buy rooms in buildings occupied by those of the same community.

The result in the BDD Chawls today is a noticeable correlation between the caste composition of a gramastha mandal and the chawl building it occupies. Many of the Maratha-only gramastha mandals linked to villages in Kolhapur District can be found in the same group of buildings, alongside Maratha families also from Kolhapur District and, in some cases, from the same villages. Similarly, the two (Dalit) Buddhist-only gramastha mandals are in buildings that are predominantly occupied by Dalit families. As I shall show in the next section but one, these living arrangements neither help to erode the 
communal divisions of the village, nor foster any great interaction between new migrants and resident families.

\section{Malls, Money and MBAs: Labour and Strategy in Post- Mill Mumbai}

Like the living space, the workplace is a sphere in which social differences have the potential to collapse or to intensify depending on the circumstances. Jan Breman (2004) has argued, in the context of mill closures in Ahmedabad, that "forms of segmentation," such as caste and religion, once "transcended by more comprehensive collective ties, such as trade union or political party" have now become dominant among ex-millworkers in the form of "narrow primordial loyalties" (p. 221). Mill closures have had far-reaching effects in Mumbai too, and it is impossible to discuss the gramastha mandals without taking the textile industry into account.

31 By the late nineteenth century, cotton mills dominated the city's industrial sector and attracted migrant labour from across western India. As a consequence, the Konkan region and increasingly the Ghats (including today's Kolhapur District) were becoming dependent on financial remittances from migrant millworkers and other laborers (Adarkar and Menon 2004:92; Chandavarkar 1994:139-40).

By the 1930s, three quarters of the city's population was employed in the cotton mills (D'Monte 2002:14), many living close by their places of work in the chawls that were being constructed to house them by mill owners, private developers and public bodies such as the Bombay Development Directorate. From around this time onwards, mills began to employ their workers in three shifts, meaning it was possible to accommodate 30 or more migrant workers in a single room, since only a third of them would require sleeping space simultaneously (Adarkar and Menon 2004:95-96; Chandavarkar 2004:21-22; Dandekar 1986:233-34; Prakash 2011:293). As Sushil, a BDD Chawls resident and self-styled local historian explained, it was precisely this concentration of potential rent-payers that made gramastha mandals economically viable in the first place.

Unsurprisingly, therefore, many older and former gramastha mandal residents I knew or knew about had at one time worked in one of the mills. Though this included both Hindus and Buddhists, it should not be assumed that there was no caste- or religion-based stratification in this sector. Despite patchy available data, there is certainly evidence to suggest that "broad occupational clusters" were formed along community lines (Chandavarkar 1994:220) and that this was at least partly driven by casteism (Adarkar and Menon 2004:112-13). In the weaving sheds, for example, the fact that workers had to wet the yarn with their mouths led to a bias among the predominantly Maratha workforce against the ritually polluting effect of lower-caste saliva (Upadhyay 2004:32).

Although it has been argued that poor urban working conditions mitigate against the formation of a stable working class (e.g. Breman 2013:71-72; De Haan 1997:928), Breman's (2004) observations on the potential of trade unions to promote cross-community ties are highly pertinent to the case of Mumbai's mills where unions flourished and striking became an "integral part" of the mill-working experience (Chandavarkar 2004:34). ${ }^{11}$ Arguably, workers' closely-maintained village connections and rural land ownership did not so much prevent their becoming "proletarianized" (De Haan 1997:944) as provide an 
economic back-stop that enabled them to "sustain strikes for extensive periods" (Chandavarkar 1994:400).

of the many strikes throughout the industry's history, that of 1982-83 is the most mythologized, ${ }^{12}$ partly because it is associated (symptomatically, if not causally) with the eventual decline and closure of the mills that occurred in the ensuing decades. The effects of this decline have been profound, not least on Mumbai's urban fabric. The "feast of hidden real estate" represented by vacant mill land (Appadurai 2000:641) has been exploited by developers, resulting in a landscape where chawls and hollowed-out shells of former mills are being engulfed by the glass and steel of business parks, high-end residences and malls. The BDD Chawls themselves have long been slated for demolition and redevelopment into apartment blocks, with a promise to rehouse existing chawl residents free of cost in the new flats. Some progress was made in this direction during my year of fieldwork, but the development program has currently stalled due to protests over lack of transparency and legally-binding resettlement agreements.

The mills no longer offering employment, there has been a marked increase in the diversity of jobs undertaken by gramastha mandal migrants today. Maura Finkelstein (2011), who briefly encountered a gramastha mandal while conducting research in a Mumbai chawl, "marvel[s] at how ... very little has changed here, aside from the industries fuelling this migration" (p. 52). While it is undeniable that, smartphones and the occasional laptop aside, there are many similarities between my observations of gramastha mandal life today and the various descriptions that exist of these institutions in the mill era, I contend that, in reality, much has changed. Many migrants now work as security guards, waiters and drivers in the malls and office complexes that occupy the former mill sites. These low-paying roles are representative of a labour market that is becoming increasingly casualized and more precarious than the mill work of earlier decades (cf. Krishnan 2000:20). A few, however, work in moderately well-paid and secure professional roles that are equally removed from the mills. These include a Civil Engineer, an Assistant IT Manager in a bank and an accountant in a hospital. Some others work in fields that are yet further from those traditionally associated with gramastha mandal migration. Among the current residents of Katkarwadi Gramastha Mandal, for example, are a web designer, a glassblower and a software engineer working on iPhone apps.

The remittance economy persists, and most of those I interviewed sent money home to their families, either through a monthly bank transfer or in a more ad hoc fashion. However, in addition to recent arrivals enjoying a grace period, a number were exempt from remitting money for longer periods and in several cases this was due to their undertaking education or training. Vinit, from Manewadi Gramastha Mandal, was training to be a radiographer and relied on his security guard brother-also living in the gramastha mandal room-to pay the fees. He told me that his family make sufficient income from their village farm and so do not require any money from him. Tukaram, meanwhile, was studying for an animation course and actually received help from his parents, who made money from their cashew farm in Katkarwadi.

Others were working and studying simultaneously, but all these cases are suggestive of a long-term family investment strategy. When, for example, Tukaram's uncle Datta came to Mumbai in the early 1970s, the only strategy available was to make money immediately and send most of it home to support his struggling family. For him, the cotton mills represented an obvious source of income. In today's precarious post-mill economy, conversely, a more logical strategy for those families who have been able to accumulate 
some capital is to invest it in training and education for their children, with a view to securing a durable source of future support.

The picture is not homogenous across gramastha mandals. Compared to many others, Katkarwadi Gramastha Mandal hosts migrants with an unusually diverse range of jobs, including a substantial number in white-collar occupations. In contrast, the residents of Shiravali Gramastha Mandal are, with one or two exceptions, security guards. Among the Buddhist migrants I met several drivers, security guards and an office assistant, as well as a few working in marketing and accounts. Their occupational range therefore appears similar to that of the majority of their Hindu counterparts, with the difference that none of the Buddhist migrants work in the better-paid corporate professions. Likewise, none of them (as far as I am aware) are currently in further education, although a few have completed undergraduate degrees in small-town institutions.

The small overall number of Buddhist gramastha mandal residents precludes my making too strong a general claim regarding the impact of caste and religion on job prospects. Nevertheless, Mhaskar's recent analyses $(2013,2018)$ of ex-millworkers' occupational choices indicate that casteism and religious discrimination persist in the new informal sector. While these studies focus particularly on anti-Muslim discrimination, a number of the factors involved, such as upper-caste karahiyat (disgust, aversion) at Muslims' perceived uncleanliness and beef-eating habits, are also applicable to Dalits (Mhaskar 2018:31).

41 An analysis of the differences between the conditions of the villages themselves is beyond the scope of this urban study. I suggest, however, that in certain instances, one highly educated or well-connected migrant can significantly influence the employment prospects of his peers in the gramastha mandal. I encountered numerous cases where newer migrants had been helped into their current job roles through personal recommendations from more established residents. This is a well-documented phenomenon in studies of migration to Mumbai (e.g. Chandavarkar 1994; Dandekar 1986; Gore 1972).

Overall, the range of jobs undertaken by gramastha mandal migrants in the post-mill era is wide, but for the most part encompasses precarious, blue-collar roles. Within my sample of interlocutors, the few who have managed to find skilled, professional work are all Hindus, although due to the small total number of Buddhist gramastha mandal residents, too firm a conclusion should not be drawn on this front. Moreover, there is little to distinguish the jobs of migrants from those of the Mumbai-born family residents of a similar age, except perhaps the number of family members in creative fields such as music, dance and the theatre.

Studies of migrant livelihoods in Mumbai have indicated a broad, if weak, correlation between the skill-level of a job and the level of inter-community mixing that occurs among workers (e.g. Gore 1972; Panjwani 1984). ${ }^{13}$ This does not bode particularly well for increased communal harmony among the gramastha mandal migrants today, since most work in low-skilled occupations. Indeed, despite the overarching similarities in job roles across migrants and family residents, my own observations indicate that few forge deep social ties at work, and when it comes to recreation, migrants are overwhelmingly thrown back on their gramastha mandals as the prime site of social activity. 


\section{Social Life and Voluntary Activity} and between migrants and family residents-can most clearly be observed. A large part of my interlocutors' social lives occurs in the gramastha mandal rooms themselves. It is common to eat together, and most gramastha mandal residents patronize an institution they refer to, in both Marathi and English, as their "mess." This is a small-scale catering business that typically operates in a family-owned chawl room, presided over by a lady known as a khanavalwali, often from the same village as her customers, or one nearby. For the relatively modest sum of around two thousand rupees per month (c. GBP 20-25), she will provide her clients, mostly single male migrants, with two cooked meals a day. The food is usually vegetarian, although on some days clients are treated to "non-veg" in the form of egg, or occasionally chicken or mutton. Once a dine-in service characterized by strong ties of loyalty between the patrons and the khanavalwalis, who were "often friends and confidantes of the migrant worker" (Adarkar and Menon 2004:97), the mess has now mostly shifted to a more business-like takeaway service model where loyalty is stretched thin. Indeed, I frequently heard complaints of boredom with mess food, and several interlocutors, including Tukaram, told me that they had changed mess more than once since moving to Mumbai.

Beyond meal times, free time is often spent simply hanging out in the room, chatting with roommates. Where a gramastha mandal owns more than one room, it is common enough for members to visit each others' rooms and spend time together, but it is somewhat less common, in my experience, for members of different gramastha mandals to socialize together on a regular basis. Noteworthy, here, are the interactions between the Hinduonly and Buddhist-only gramastha mandals linked to the same village. Pravin, a Buddhist from Amrutwadi, told me that Ambedkar himself had visited his room in the 1950s to broker peace following an outbreak of Mahar-Maratha rioting. Nowadays, he and his roommates assured me, relations between Amrutwadi's Buddhist and Hindu communities are calm and trouble-free. This tallied with the impression I formed, through observations and chance remarks, that relationships between Hindu and Buddhist migrants from the same village were generally amicable, if somewhat distant. Ananda, from the same Buddhist gramastha mandal as Pravin, told me that he mixed socially with the Hindus from his village who lived in a separate building, and that he and other Buddhists from the village had attended the annual puja (ritual prayer) in the Hindu room.

However, the lack of animosity between the communities does not alter the structure of gramastha mandal living, in which in-group socializing is far easier than socializing between groups. When I asked members of the Hindu-only Borgaon Gramastha Mandal if they could accompany and introduce me to members of the Buddhist-only Borgaon Gramastha Mandal, they seemed bemused by my interest and told me it would be difficult for me to meet the Buddhists as they (the Hindus) did not know their work schedules. Weeks later, Hindu Vaibhav introduced me to Anil, one of the Borgaon Buddhists, as an old school friend with whom he seemed to be on cordial terms. When I subsequently returned to the Borgaon Buddhist room alone, Anil told me that despite living close by, he and Vaibhav met infrequently because they were both so busy at work. In-group socializing is simply the everyday outcome of being in the gramastha mandal room, while a

South Asia Multidisciplinary Academic Journal, 21 | 2019 
Hindu wishing to meet up with a Buddhist from the same village needs to make a conscious effort to bridge the gap between separate living spaces and uncertain schedules. Despite the proximity of the rooms in many cases, this does not appear to be an entirely trivial endeavor.

If the interaction between gramastha mandals is limited, that between gramastha mandals and chawl families is, in most cases, even more so. My interlocutors who lived with their families, whether Maratha or Buddhist, referred to gramastha mandals in dismissive terms and seemed to find my interest in them either puzzling or amusing. There was a perception among some of the gramastha mandal migrants that their family neighbors regarded them as drunken trouble-makers. One interlocutor from Amrutwadi even told me that when his roommates got especially rowdy, the families down the corridor would threaten to call the police. On another occasion, a middle-aged family man from the building opposite explained there were no gramastha mandals in his chawl, because "We don't allow. We don't like it. They keep the room dirty, chewing tobacco."

Rowe (1973) has observed that even after living in Mumbai for several decades, migrants' continued investment in their villages means that they "remain at the far end of the continuum of involvement in city life," which includes making "relatively little contact" with Mumbai's voluntary organizations (p. 232-35). This rings true in the BDD chawls, where gramastha mandal migrants, by and large, have very little involvement with the numerous clubs and committees that organized religious functions, sports competitions and a range of social welfare activities. These organizations, known as mitra mandals (friends' associations), are typically linked to a specific chawl building or pair of buildings and have been described elsewhere as "a prominent feature of popular life in Bombay" and an important site of "cultural interaction, and slow integration of the newcomers." (Heuzé 1995:219).

There was little evidence of "slow integration" of gramastha mandal newcomers into the mitra mandals. In Tukaram's chawl, for instance, most of the family members belonged to an organization called the Bandya Maruti Seva Mandal which was renowned for its kabaddi $^{14}$ team and its prowess in building human pyramids during the (Hindu) Dahi Handi festival. When I asked gramastha mandal members if they belonged to the organization, the usual response was a derisive laugh and an explanation that mitra mandals were for families, not bachelors like them. Just as the families I knew were baffled by my interest in gramastha mandals, Tukaram was dismissive of the Bandya Maruti Seva Mandal and appeared annoyed whenever I brought up the subject. Confident and charismatic as he was in the comfort of the gramastha mandal room, he often appeared shy in the vicinity of the young men from the mitra mandal who tended to dominate the semipublic spaces outside the building. In fact, this was entirely in keeping with the view I heard from these Bandya Maruti Seva Mandal members, who found the gramastha mandal migrants unaccountably shy despite their having been invited on many occasions to join the activities of the mitra mandal (or so, at least, these members claimed).

51 Migrants the world over risk being accused of a failure to integrate. What sets the case of the gramastha mandals and the mitra mandals apart from many other migration studies, including Rowe's (1973) account of Mumbai migrants from Uttar Pradesh, is the extreme similarity between the gramastha mandal residents and their family neighbors according to most demographic yardsticks. Both groups speak Marathi, both are dominated by Hindu Marathas, and the families in Tukaram's chawl overwhelmingly trace their roots to 
the same small area in the south of Kolhapur District. Most families, indeed, are living where they are as a result of an earlier gramastha mandal migration experience.

The only substantive differences are those of lifestyle, magnified by mutual negative perceptions, and the distinctive urban identity that has emerged among second, third or even fourth generation migrants and has been intensified through the social activities of the mitra mandals that transcend ancestral village boundaries. According to many chawl residents, in fact, the mitra mandals themselves were initially established by gramastha mandal migrants, and it was only when some of their founder members settled down with their wives and children in the chawls that the mitra mandals transformed into familyorientated organizations. These founder members, unwilling to hand over responsibility to new migrants, instead passed on the baton to their (often) Mumbai-born children. The social composition of organizations like the Bandya Maruti Seva Mandal has hence shifted over time towards a more family-dominated demographic, to the exclusion of newer gramastha mandal migrants.

53 It is not the case, however, that my gramastha mandal interlocutors did not take part in any organized social, political or voluntary activity. Few have joined the electoral register in Mumbai, but many return to the village to cast their vote. For some, the five-yearly gram panchayat (village council) elections are of much greater consequence than national or state elections, and some gramastha mandals charter a minibus to facilitate their members' participation. Furthermore, many migrants are actively involved in welfare organizations that help to finance improvements to village schools or infrastructure. These welfare organizations are often tied directly to the gramastha mandal and their interventions sometimes have a specifically communal end in view, such as the construction of a new Hindu temple or Buddhist cultural center. In short, not only do the social and cultural structures that emerge from the gramastha mandal system help to perpetuate the communal divisions found in the village, but they also do nothing to promote the social integration of new migrants and their family neighbors.

\section{Changes and Continuities}

Despite his love of Katkarwadi, Tukaram has no aspirations to return there permanently. The future plans he relayed to me were characteristically fluid, but other than the flights of fancy that took him far from the BDD Chawls to Singapore, Oman or, at the very least, Bangalore, he mostly talked about buying a flat with financial support from his father in one of Mumbai's satellite cities like Thane or Panvel. Although not many of my other interlocutors could count on parental assistance in this way, over half of them voiced similar plans to buy property in these or other suburban areas where property prices are significantly cheaper than in the central parts of the city. Several had, in fact, already bought a flat that they were renting out to tenants while they continued to live in the BDD Chawls, usually with a view to moving after marriage.

Another change that is at least in part an effect of the mill closures is a reduction in the number of those coming to live in gramastha mandals. As a result, some gramastha mandals now take in occupants from different villages, while others rent out or sell one or more of their rooms to families from their own villages. In a few instances, formerly Hindu-only gramastha mandals have opened their doors to Dalit Buddhists. Shiravali Gramastha Mandal, while still dominated by Marathas, now includes a few Dalit Hindus and Dalit 
Buddhists among its residents. One of the older Maratha room members explained this relaxation in eligibility criteria as a result of the more conservative men of his father's generation having left the room and retired to the village. Given the more general decline in gramastha mandal numbers, however, I suggest that this change should also be viewed as a deliberate strategy to broaden the pool of potential rent payers. At least one of the Buddhist room members is a security guard, like the majority of the Hindu residents, and he appeared to integrate fully in the social life of the room.

I encountered three other gramastha mandals with similarly relaxed eligibility rules.

Another, while currently restricted to Marathas, had nonetheless relaxed an even more stringent earlier policy that restricted occupation to Maratha millworkers and their descendants. A younger resident told me that he found the Maratha-only rule oldfashioned, and that he would personally have no problem opening the room to Buddhists and other communities.

The impact that this relaxing of eligibility rules is having on social relations back in the villages is unclear. Dipankar Gupta (2005), reflecting on the contemporary Indian village in general, argues that a "gradual diminution of status of the dominant castes" has occurred in tandem with the "assertion of [marginalised] caste identities," meaning that aside from "pockets of upper caste intransigence ... [u]ntouchability is not practiced widely" (p. 753-57). Dalit scholar Anand Teltumbde (2007) is less optimistic, arguing that the notorious 2006 anti-Dalit massacre in Khairlanji village explodes the "myths" that "economic development does away with casteism" or that "there exists a significant progressive section of non-dalits that is against the caste system" (p. 1019).

Back in the 1980s, Dandekar (1986) reflected that migrants typically "adopt more progressive attitudes...than those who stay behind," meaning that if "caste and class relationships are to be jolted into the countryside, the impetus will probably have to come from the city." (p. 254-56). My interlocutors themselves seem divided on this issue, with some painting caste relations in their village today in a rosy light, and others gloomily predicting the persistence of casteism for many years to come. There was no clear division of opinion on this matter between Hindus and Buddhists.

Thinking back to the limited social interaction between the Hindu and Buddhist gramastha mandal migrants in the BDD Chawls, and the caste-based organizations that channel funds from Mumbai to the village, frequently with caste-specific ends in view, Dandekar's prognosis appears rather optimistic. Inclusivity may have taken root in a few gramastha mandals, but in the majority, the mid-twentieth century village attitudes of their founders are kept alive through exclusionary eligibility policies. The attitudes are reinforced by the demographics of the surrounding chawl buildings, themselves a resultin part, at least-of the historic tendency of bachelor migrants to settle with their families in the same or a nearby building. Work opportunities in the post-mill era appear to provide limited impetus for migrants to mix extensively outside their own homogenous circles and, for now, gramastha mandals are still the principle locus of social interaction.

60 It remains to be seen whether and how this situation will be impacted by the emergence of a substantial new generation of suburban homeowners. Today, however, several former gramastha mandal residents already live with their families in suburban apartments, and many of these still maintain close ties with both their gramastha mandal and their village. These links, it seems, are not easily broken. 


\section{BIBLIOGRAPHY}

Adarkar, Neera. 2003. "Gendering of the Culture of Building: Case of Mumbai." Economic \& Political Weekly 38(43):4527-34.

Adarkar, Neera. 2011. The Chawls of Mumbai: Galleries of Life. edited by N. Adarkar. Delhi: imprintOne.

Adarkar, Neera and Meena Menon. 2004. One Hundred Years, One Hundred Voices - the Millworkers of Girangaon: An Oral History. Calcutta: Seagull Books.

Appadurai, Arjun. 2000. "Spectral Housing and Urban Cleansing: Notes on Millennial Mumbai." Public Culture 12(3):627-51.

Breman, Jan. 2004. The Making and Unmaking of an Industrial Working Class : Sliding down the Labour Hierarchy in Ahmedabad, India. New Delhi : Oxford University Press,.

Breman, Jan. 2013. At Work in the Informal Economy of India: A Perspective from the Bottom Up. New Delhi: Oxford University Press.

Caru, Vanessa. 2004. “The Making of a Working-Class Area, the Worli BDD Chawls (1920-40)." Pp. 26-36 in One hundred years one hundred voices : the millworkers of Girangaon: an oral history/, edited by N. Adarkar and M. Menon. Calcutta : Seagull Books,.

Caru, Vanessa. 2011. “The Making of a Working-Class Area, the Worli BDD Chawls (1920-40).” Pp. 26-36 in The Chawls of Mumbai: galleries of life, edited by N. Adarkar. Delhi: imprintOne.

Chandavarkar, Rajnarayan. 1994. The Origins of Industrial Capitalism in India : Business Strategies and the Working Classes in Bombay, 1900-1940 /. Cambridge ; New York: Cambridge University Press,.

Chandavarkar, Rajnarayan. 2004. "From Neighbourhood to Nation: The Rise and Fall of the Left in Bombay's Girangaon in the Twentieth Century." Pp. 7-80 in One hundred years, one hundred voices the millworkers of Girangaon: an oral history, edited by N. Adarkar and M. Menon. Calcutta: Seagull Books.

Dandekar, Hemalata C. 1986. Men to Bombay, Women at Home : Urban Influence on Sugao Village, Deccan, Maharashtra, India, 1942-1982. Ann Arbor : Center for South and Southeast Asian Studies, the University of Michigan,.

De Haan, Arjan. 1997. "Migrant Workers and Industrial Capitalism in Calcutta." Modern Asian Studies 31(4):919-49.

Deshingkar, Priya and John Farrington, eds. 2009. Circular Migration and Multilocational Livelihood Strategies in Rural India. New Delhi ; New York: Oxford University Press.

D'Monte, Darryl. 2002. Ripping the Fabric: The Decline of Mumbai and Its Mills /. New Delhi; Oxford; Toronto : Oxford University Press,.

Finkelstein, Maura. 2011. "The Chronotype of a Chawl: A Ghost Story in Three Acts." Pp. 49-57 in The Chawls of Mumbai: galleries of life, edited by N. Adarkar. Delhi: imprintOne.

Gidwani, V. and K. Sivaramakrishnan. 2003. "Circular Migration and Rural Cosmopolitanism in India." Contributions to Indian Sociology 37(1-2):339-67. 
Glaeser, Edward. 2011. The Triumph of the City: How Urban Spaces Make Us Human. London: Macmillan.

Gore, M. S. 1972. Immigrants and Neighbourhoods: Two Aspects of Life in a Metropolitan City. Gupta, Dipankar. 2005. "Whither the Indian Village: Culture and Agriculture in 'Rural' India." Economic and Political Weekly 40(8):751-58.

Hansen, Thomas Blom. 2001. Wages of Violence : Naming and Identity in Postcolonial Bombay /. Princeton, N.J. : Princeton University Press,.

Hansen, Thomas Blom and Oskar Verkaaik. 2009. "Introduction - Urban Charisma: On Everyday Mythologies in the City." Critique of Anthropology 29(1):5-26.

Heuzé, Gerard. 1995. "Cultural Populism: The Appeal of the Shiv Sena.” Pp. 213-47 in Bombay: metaphor for modern India, Oxford India Paperbacks, edited by S. Patel and A. Thorner. Bombay: Oxford University Press.

Ilaiah, Kancha. 1996. Why I Am Not a Hindu : A Sudra Critique of Hindutva, Philosophy, Culture, and Political Economy /. Calcutta : Bombay : Samya; Distributed by Bhatkal Books International,. Krishnan, Shekhar. 2000. “The Murder of the Mills: A Case Study of Phoenix Mills.”

Mhaskar, Sumeet. 2013. "Encountering 'Inclusion' and Exclusion in Post-Industrial Mumbai: A Study of Muslim Ex-Millworkers' Occupational Choices." in Navigating Exclusion, Inclusion Engineering: Entangled Social Processes in India, 149-163, edited by U. Skoda, K. B. Nielsen, and M. Q. Fibiger. London: Anthem Press.

Mhaskar, Sumeet. 2018. "Ghettoisation of Economic Choices in a Global City: A Case Study of Mumbai." Economic \& Political Weekly 53(29):29-37.

Panjwani, Narendra. 1984. "Living with Capitalism: Class, Caste and Paternalism among Industrial Workers in Bombay." Contributions to Indian Sociologu 18(2):267-92.

Pawar, Daya. 2009. “We Are Kings (an Extract from 'Baluta').” Pp. 98-105 in Poisoned Bread: translations from modern Marathi Dalit literature, edited by A. Dangle. Hyderabad: Orient BlackSwan,.

Pendse, Sandeep, Neera Adarkar, and Maura Finkelstein. 2011. “Overview.” Pp. 1-11 in The Chawls of Mumbai: galleries of life, edited by N. Adarkar. Delhi: imprintOne.

Prakash, Gyan. 2011. Mumbai Fables: A History of an Enchanted City. Princeton: Princeton University Press.

Public Works Department. 1922. “File No 35/II ‘Tenders - Development Department Chawls.”' Public Works Department. 1924. "File No 65/3 'Petition from Mr V M Hassan for the Fragment of His Bills in Connection with the Construction of Chawls at Delisle Road."

Public Works Department. 1925. "File No 65A/10 "Petition from Messrs J.C. Gammon Ltd, Contractors, for Payment of Bills in Connection with the Construction of Chawls at Delisle Road."."

Public Works Department. 1938. “File No 2032/36-I (1937-8).”

Rao, Anupama. 2009. The Caste Question : Dalits and the Politics of Modern India /. Berkeley: University of California Press.

Rowe, W. L. 1973. “Caste, Kinship and Association in Urban India.” Pp. 211-50 in Urban anthropology: cross-cultural studies of urbanization, edited by A. W. Southall. New York: Oxford University Press. 
Saunders, Doug. 2011. Arrival City: How the Largest Migration in History Is Reshaping Our World. London: Windmill Books.

Shetty, Prasad. 2011. “Ganga Building Chronicles.” Pp. 58-66 in The Chawls of Mumbai: galleries of life, edited by N. Adarkar. Delhi: imprintOne.

Teltumbde, Anand. 2007. "Khairlanji and Its Aftermath: Exploding Some Myths." Economic and Political Weekly 42(12):1019-25.

Teltumbde, Anand. 2009. "Reservations within Reservations: A Solution." Economic and Political Weekly 44(41/42):16-18.

Upadhyay, Shashi Bhushan. 2004. Existence, Identity and Mobilization : The Cotton Millworkers of Bombay, 1890-1919/. New Delhi: Manohar.

Valunjkar, T. N. 1966. Social Organization, Migration and Change in a Village Community. Poona: Deccan College.

\section{NOTES}

1. All names of individuals and villages have been altered to protect the identities of my research participants.

2. The research drawn upon in this paper was conducted between January 2017 and January 2018 with the help of funding from the Economic and Social Research Council, and a SOAS fieldwork grant.

3. For simplicity, I use the name "Mumbai" throughout this paper, even when referring to the city prior to its renaming in 1995. Where other authors have used "Bombay," I have retained their usage.

4. Forward caste refers to Hindu communities that do not qualify for government affirmative action schemes, unlike Dalits, tribal communities, and the "Other Backward Classes" grouping. Since Marathas have recently been awarded a reserved quota in education and public sector jobs, it is unclear whether this label will continue to apply in future.

5. A vernacular Marathi equivalent of gramastha.

6. There is also a persistent rumour that the BDD Chawls were constructed by the British as jails. Although records indicate that some of the buildings in the Worli site were temporarily used for this purpose in the 1930s and '40s (Caru 2011:30), I have found no evidence in the Maharashtra State Archives to suggest that this was also the case in Delisle Road. Original tender documentation and correspondence clearly indicates that the buildings were constructed for residential purposes (e.g. Public Works Department 1922, 1924, 1925, 1938).

7. Ananda, interview $7 / 1 / 18$, my translation from Hindi.

8. Ananda, interview $7 / 1 / 18$, my translation from Hindi

9. Abhinav, interview in English, 11/12/17.

10. For specific examples of spatial divisions in Maharashtrian villages see also Valunjkar (1966:8-16), Dandekar (1986:54-62) and Dalit writer Daya Pawar's autobiography Baluta (2009:98).

11. Chandavarkar (1994) points out that even though trade unions took care to "distinguish themselves from caste organisations," in some cases support was derived from specific caste groups (p. 427), thus mitigating their potential to forge a unified working class.

12. Adarkar and Menon's (2004) One hundred years, one hundred voices and Darryl D'Monte's (2002) Ripping the fabric are noteworthy among the numerous detailed accounts of this famous strike and its aftermath respectively. 
13. As Breman (2013) explains, employers often recruit migrants to fill low-paying, precarious roles in order to maintain a "pliable and vulnerable" workforce that does "not easily team up in collective action" but, rather, remains "divided along lines of caste, ethnicity, religion, and other primary loyalties" (p. 66-72).

14. Kabaddi is a popular Indian contact sport.

\section{ABSTRACTS}

Drawing on a year's fieldwork in the Mumbai BDD Chawls neighborhood, this paper analyses an urban migration phenomenon called the gramastha mandal. Gramastha mandals are village-run committees that buy chawl (tenement) rooms and rent them to single male migrants from their own villages. Save a few studies and cursory references, gramastha mandals have received limited academic attention, especially in today's climate of economic liberalization following the widespread closure of Mumbai's cotton mills. Through an examination of gramastha mandal living arrangements, working patterns and social activities, I answer three broad questions. Firstly, how have the gramastha mandals been impacted by the closure of the mills that once provided a major source of employment? Secondly how does living in a gramastha mandal room impact migrants' relationships with the city around them and, thirdly, how does this arrangement perpetuate societal divisions from the village? I suggest that most gramastha mandal residents remain more part of their villages than of Mumbai's social structures, and that this alienation has increased since the mills closed and opportunities for forging a working-class urban solidarity correspondingly declined. Moreover, through strict eligibility criteria, gramastha mandals replicate, rather than erode, village fault-lines between caste Hindu and Dalit Buddhist communities, a phenomenon that shows only limited signs of changing.

\section{INDEX}

Keywords: Mumbai, circular migration, village, chawl, caste, Maratha, Dalits

\section{AUTHOR}

\section{JONATHAN GALTON}

School of Oriental and African Studies, London 